FOLIA

Amazónica

Revista del Instituto de Investigaciones

de la Amazonía Peruana

\title{
COMPOSITION OF THE ICHTHYOFAUNA OF THE IGARAPÉ PRAQUIQUARA, CASTANHAL, EASTERN AMAZON
}

\author{
Rafael Anaisce DAS CHAGAS ${ }^{1}$, Mara Rúbia FERREIRA BARROS ${ }^{1}$, \\ Wagner César ROSA DOS SANTOS ${ }^{1}$, Alan Patrick SOUZA MIRANDA', \\ Renata FRANCO DOS SANTOS ${ }^{1}$, Lucas BRASIL DUARTE ${ }^{1}$, \\ Camila Maria BARBOSA PEREIRA ${ }^{1}$, Geyseanne Suely TEIXEIRA NORONHA ${ }^{1}$, \\ Lorena Cristina DOS REIS DE BRITO ${ }^{1}$, Marko HERRMANN ${ }^{1}$
}

\footnotetext{
1 Universidade Federal Rural da Amazônia (UFRA), Instituto Socioambiental e dos Recursos Hídricos (ISARH), Av. Presidente Tancredo Neves, 2501-Post Box n 917, Bairro: Montese, CEP: 66077-530, Belém, Pará-Brazil.

Correo electrónico: rafaelanaisce@hotmail.com
}

\begin{abstract}
In the Amazon basin it is distributed the greatest diversity of freshwater fish in the world, but presents less than half of the species described and/or with little knowledge about its biology and distribution. This work presents the composition of the ichthyofauna Igarapé Praquiquara, located in the municipality of Castanhal, belonging to the Northeast Atlantic Hydrographic Region, Brazil, through collections were conducted in the years 2014 and 2015. A total number of 1,073 fish were sampled, belonging to five orders, 16 families, 35 genus and 42 species. Characiformes and Perciformes were the most predominant orders, Cichlidae and Characidae were the most abundant families, and Bryconops giacopinni, Cyphocharax gouldingi, Astyanax sp., Geophagus proximus and Satanoperca jurupari the most abundant species. Igarapé Praquiquara is composed of species with moderate commercial interest for commercial aquariums, with the presence of species cultivated in other regions. A structural analysis of the igarapé fish community is recommended in order to identify which factors are responsible for the composition of the ichthyofauna present, as well as the influence of the dam on the dispersion, distribution and reproduction of species.

KEYWORDS: Amazon basin, Amazonian fish, biodiversity, ichthyofauna, "Igarapé Praquiquara".
\end{abstract}




\title{
COMPOSICIÓN DE LA ICTIOFAUNA DEL IGARAPÉ PRAQUIQUARA, CASTANHAL, AMAZONIA ORIENTAL
}

\begin{abstract}
RESUMEN
En la cuenca del Amazonas se distribuye la mayor diversidad de peces de agua dulce del mundo, pero menos de la mitad de las especies estan descritas, se conoce muy poco sobre su biología y distribución. Este trabajo presenta la composición de la ictiofauna de arroyo Igarapé Praquiquara, ubicada en el municipio de Castanhal, perteneciente a la Región Hidrográfica del Atlántico Noreste, a través de colecciones realizadas en los años 2014 y 2015. Se muestrearon un total de 1,073 peces, pertenecientes a cinco órdenes, 16 Familias, 35 géneros y 42 especies. Hubo predominio de Characiformes y Perciformes, con mayor abundancia de las familias Cichlidae y Characidae, y las especies más abundantes fueron Bryconops giacopinni, Cyphocharax gouldingi, Astyanax sp., Geophagus proximus y Satanoperca jurupari. La ictiofauna del Igarapé Praquiquara está compuesta por especies de interés comercial moderado dirigidas al acuario, con la presencia de especies cultivadas en otras regiones. Se recomienda un análisis estructural de la comunidad de peces Igarapé para identificar qué factores son responsables de la composición de la ictiofauna presente, así como la influencia de la presa en la dispersión, distribución y reproducción de la especie.
\end{abstract}

PALABRAS CLAVE: Cuenca Amazónica, biodiversidad, peces amazónicos. 


\section{INTRODUCTION}

The Neotropical region (part of Central America and the southern part of the continent) is estimated to contain between 8,000 and 9,000 species of freshwater fish described, with Brazil harboring the greatest diversity of these species, about 21\% (Buckup et al., 2007; Nogueira et al., 2010). Within the Neotropical region, the Amazon is worth mentioning, because it presents a great diversity of water bodies, composed of numerous small streams that contribute to the formation of large rivers (Cáuper, 2006).

Despite recent genetic studies and the discovery/description of new species, all fish remain far from being fully documented and studied (Nogueira et al., 2010). However there are estimates that the diversity of fish in the Amazon basin is around 5,000 species (LoweMcConnell, 1999). In contrast, Nogueira et al. (2010) comments that in spite of the current advances in the knowledge of the ichthyofauna, species extinctions occur in Brazilian freshwater, and many species may be under threat even before they are formally described or studied in basic aspects of natural history.

The composition of the ichthyofauna of a water body is related to several factors, among them: local environmental conditions, landscape characteristics, climatic variations occurring at different temporal scales, characteristics of the regional set of species, historical factors, as well as intrinsic species characteristics (Bastos, 2013; Brejão et al., 2013).

Knowledge of fish composition is an initial and indispensable step to obtain basic information to foster management actions and preservation of an area (Montag et al., 2008). In this context, the present study presents the composition of the ichthyofauna of the Igarapé Praquiquara, located in the municipality of Castanhal, belonging to the Northeast Atlantic Hydrographic Region, Brazil, through collections made in the years 2014 and 2015 .

\section{MATERIALS AND METHODS}

\section{STUDY AREA}

The Igarapé Praquiquara located in the region of the middle Apeú River, located in Castanhal, Eastern Amazon (Figure 1), $63 \mathrm{~km}$ close to the BR 316 highway, in an area belonging to the Hydrographic Atlantic Northeast Region, conforming the basins of the Guamá-Moju, Gurupí and Atlantic basins (Pará, 2012). The springs of the Igarapé are located within the Instituto Federal do Pará (IFPA - Campus Castanhal) and along the right and left bank is the Fazenda Escola de Castanhal of the Universidade Federal Rural da Amazônia (FEC/UFRA) (Santos \& Chagas, 2016).

The weather of the region is characterized by humid metamorphic equatorial, corresponding to the Ami type, according to the classification of Köppen. According to Silva et al. (2011), it presents high temperature with an average of 25 ${ }^{\circ} \mathrm{C}$, maximum close to $40{ }^{\circ} \mathrm{C}$, but with small thermal amplitudes, abundant precipitation, about 2,200 $\mathrm{mm}$ year-1 and relative humidity between $85 \%$ and $90 \%$. Moraes et al. (2005) mentioned that the seasonal variation of the region is divided in a rainy season (December to May) and by a less rainy season, characterized by "dry period" (June to November).

All collections were carried out between September 2014 and May 2015, collecting during the dry and rainy periods. The collections were performed at six points along the Igarapé Praquiquara, one at the dam level and the other sampling points in the course of the water body. Point 1 (P1) (Figure 1) corresponds to the flooded area after the construction of the dam, presenting the greater depth than the other points, where tambaqui (Colossoma macropomum Cuvier, 


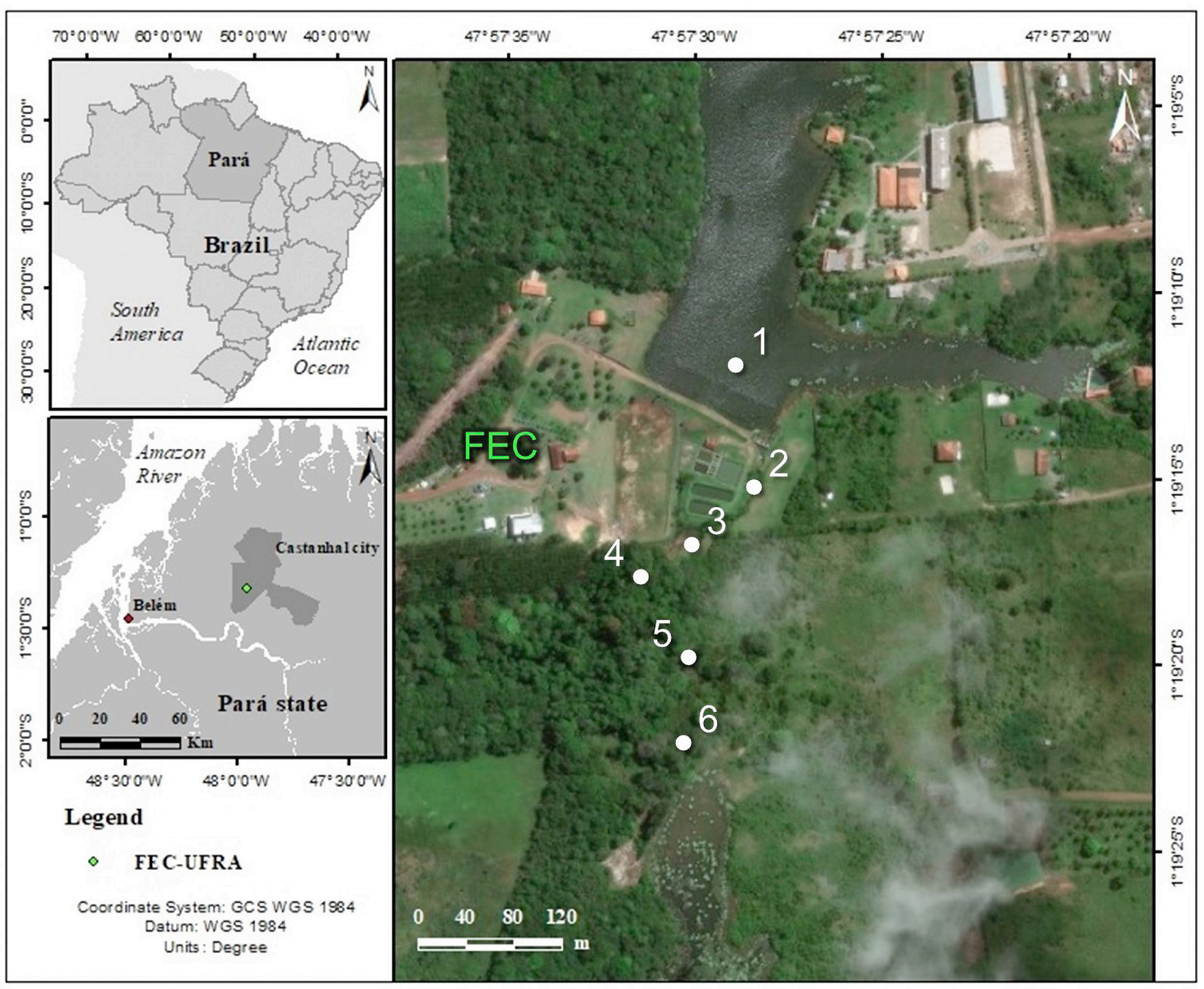

Figure 1: Location of sampling points in Igarapé Praquiquara, Eastern Amazonia, Brazil.

1818) is cultivated in tanks-nets. Point 2 (P2) (Figure 1) is delimited between the spillway of the dam (downstream) and the settling basin. Point 3 (P3) (Figure 1) delimits the portion of the Igarapé that functions as the settling basin of the FEC fish farm. Points 4, 5 and 6 (respectively, P4, P5 and P6) correspond to the course of the Igarapé Praquiquara which presents dense semi-enclosed vegetation cover.

\section{SAMPLING METHODOLOGY}

The paraphernalia used were: hand trawls, trawls, gillnet and "tarrafas". The mesh sizes of the fishing nets, as well as the points in which they were used, are described in Table 1 . The use of the waiting network 3 and 4 only in P1 and P2 occurred due to the network dimensions (100 meters in length and 2 meters in height), making it impossible to insert these devices in the other points. With the same justification, nets 1 and 2 were inserted only at points $\mathrm{P} 1$ to $\mathrm{P} 4$, because points P5 and P6, the depth does not exceed 0.6 $\mathrm{m}$, using only the tarrafa and the hand and drag.

Waiting nets were installed in the morning, afternoon and evening, making observations every four hours (except during dawn). This 
procedure systematized and guaranteed the same collection effort for all sampling stations. The other method of sampling is considered random, with the use of flasks, gillnets and hand net. The flasks were operated with six bids at each station, the hand and trawl nets were operated ten times per sampling station randomly and adjacent to the sample stations where the gill nets were installed.

Captured fish were photographed and released again in the "Igarapé", thus avoiding the mass mortality of the biota. The images made in a photographic camera on an ichthyometer, enabled the taxonomic identification through the external morphological characteristics and the later morphometric analysis of the species found.

Fish sampled were identified at the lowest possible taxonomic level according to available literature (Géry, 1977; Santos et al., 1984; Cervigón et al., 1992; Santos et al., 2004; Nelson, 2006; Santos et al., 2006; Soares et al., 2008; Zuanon et al., 2008; Queiroz et al., 2013c, 2013b, 2013a; Vieira et al., 2016).

After the taxonomic identifications, the presence of the fish in the red list of endangered species of the International Union for Conservation of Nature and Natural Resources (IUCN) (http:// www.iucnredlist.org), identifying the category in which the species are classified.

\section{DATA ANALYSIS}

The composition of the community was described through ecological indexes, such as constancy, relative abundance, absolute wealth (Krebs, 1978).

The constancy (C) expresses the relation between the number of samples in which a particular species is present and the total number of samples carried out, being expressed by equation $C=\frac{N i}{N} \times 100$, where $N i$ is the number of samples that species $i$ is present and $N$ is the total number of samples. According to Rodrigues (2010), C > 50\% are considered constant species,
$25 \geq \mathrm{C}<50 \%$ are considered as ancillary species and below $\mathrm{C}<25 \%$ are considered as accidental species. The relative abundance (Ab) expressed between the abundance ratio of a given species and the total abundance of individuals found, is expressed by the following equation $C=\frac{A i}{A t} \times 100$, where $A i$ is the abundance of species $i$ and $A t$ the total abundance of individuals. The absolute wealth $(S)$ simply expresses the total number of species observed at the end of sampling.

\section{RESULTS}

The dataset of the abundance and diversity of the ichthyofauna of the Igarapé Praquiquara are available in Chagas et al. (2017), on the digital platform PANGAEA (Data Publisher for Earth \&Environmental Science).

A total of 1,073 fish were sampled, belonging to five orders (Characiformes, Perciformes, Siluriformes, Gymnotiformes and Beloniformes), 16 families, 35 genera and 42 species. The diversity of species presented a mean of $17.12 \pm 3.75$ (mean \pm SD), ranging from 10 (May/2015) to 21 (February/2015) species and in number of individuals with a mean of 1134.12 \pm 30, 29, between 97 (December 2014) and 189 (January/2015) (Figure 2). The rainy season was superior in abundance of individuals (662 ind.) And species diversity (34 spp.) Compared to the "dry" period, with 4111 individuals and 33 species.

Characiformes was more abundant in number of families (56.3\%, represented by nine families), followed by Perciformes, Siluriformes, and Gymnotiformes (12.5\%, with two families each) and Beloniformes (6.3\%, with only one family). The systematic list of fish species found in the Igarapé Praquiquara is shown in Table 1, in systematic order from highest to lowest taxonomic level. 


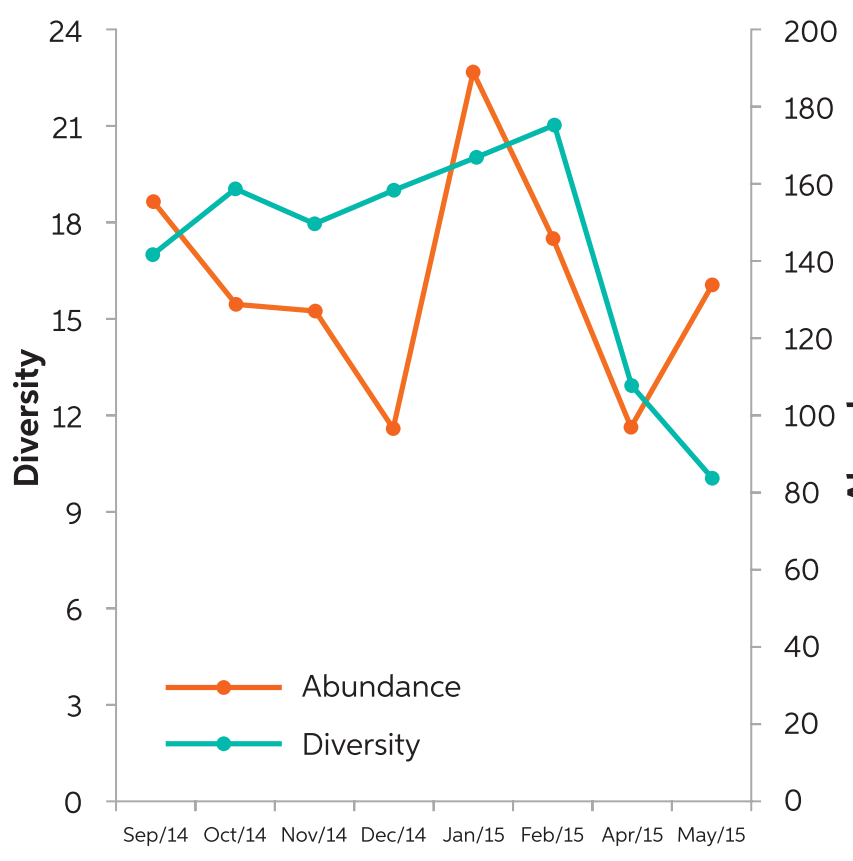

Figure 2. Time variation of the abundance of individuals and species diversity.

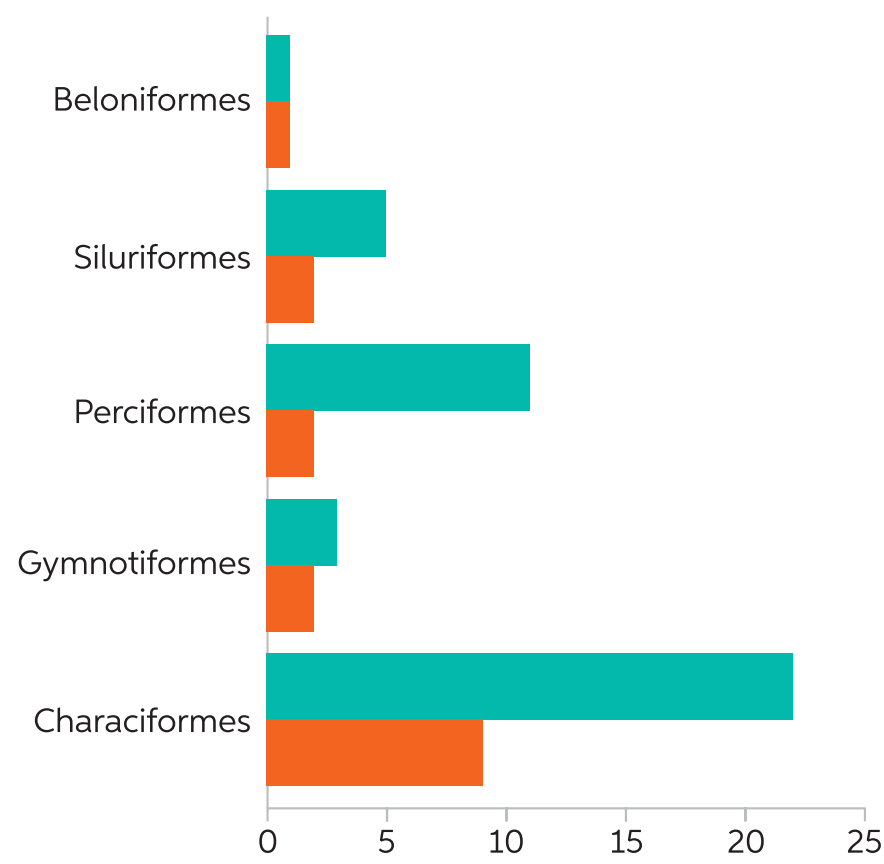

Figure 3. Diversity of species and families by order of the ichthyofauna found in the Igarapé Praquiquara.

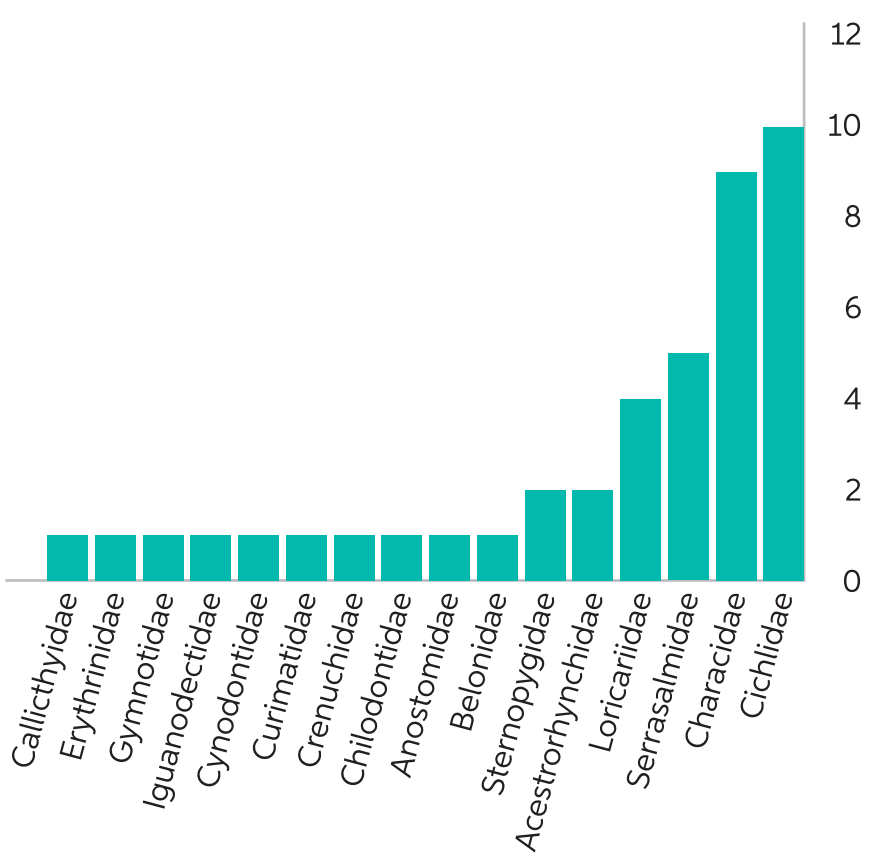

Figure 4. Diversity by family of the ichthyofauna found in the Igarapé Praquiquara.

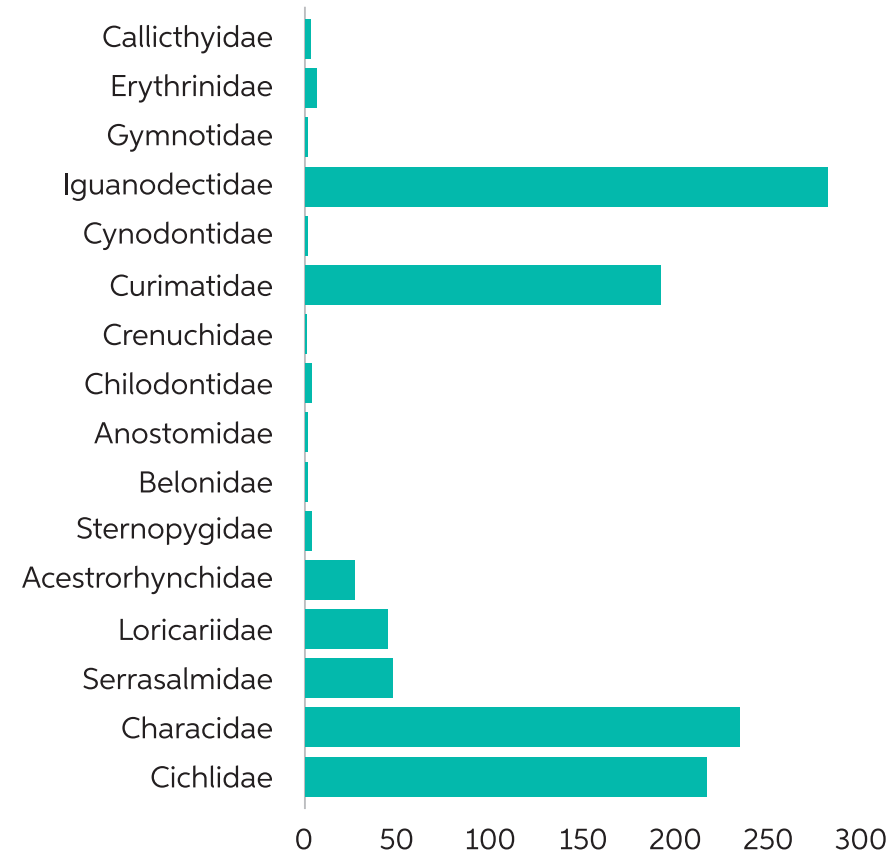

Figure 5. Plenty of individuals per family of the ichthyofauna found in the Igarapé Praquiquara. 
a

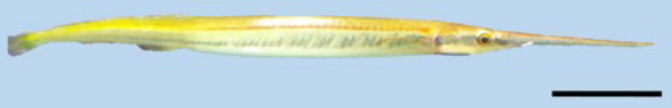

C

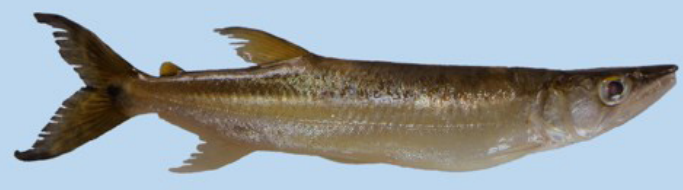

e

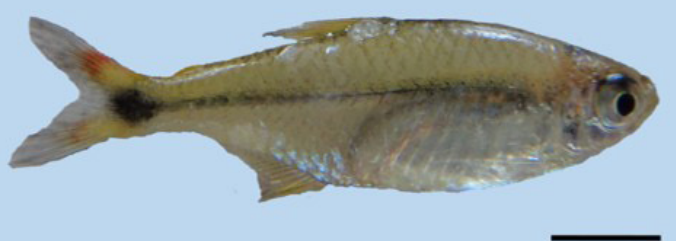

g

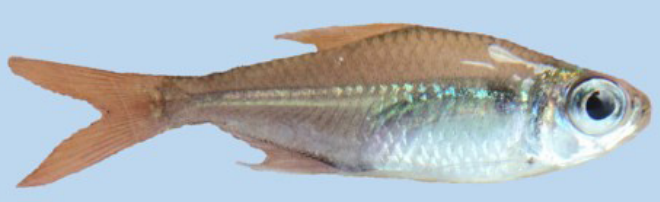

i

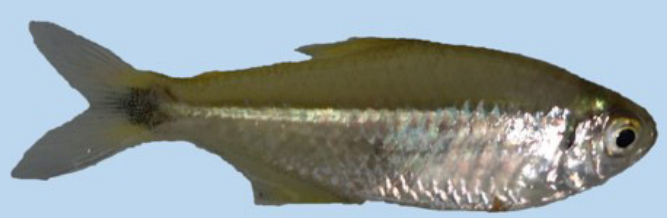

k

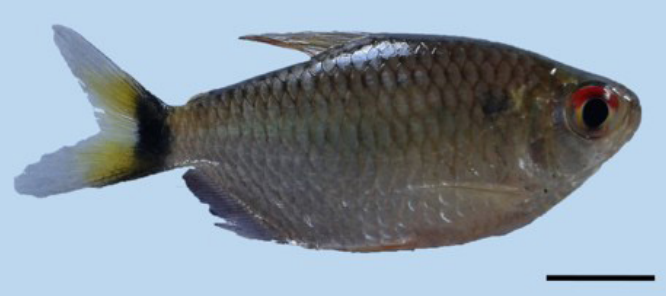

b

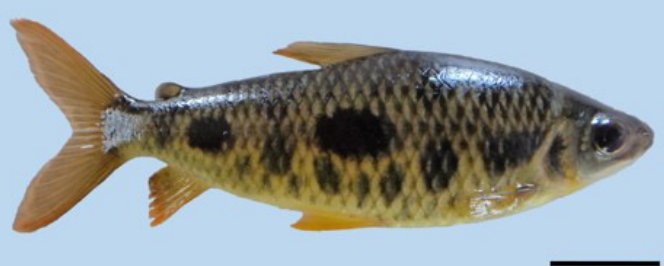

d

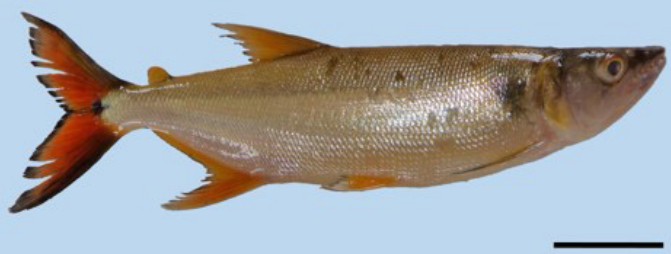

f

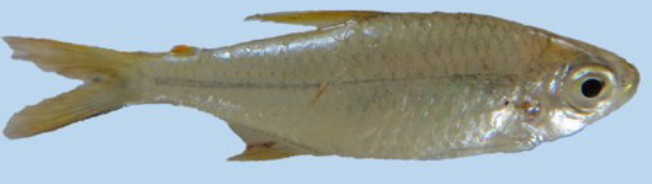

h

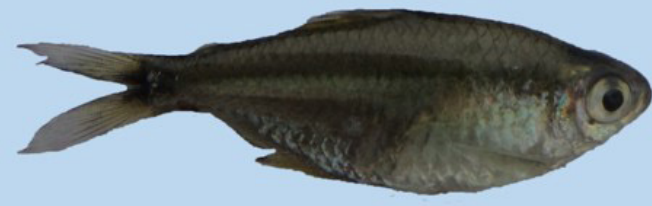

j

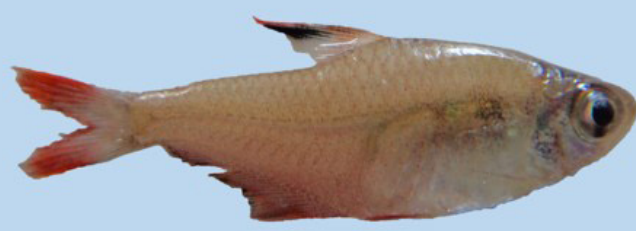

I

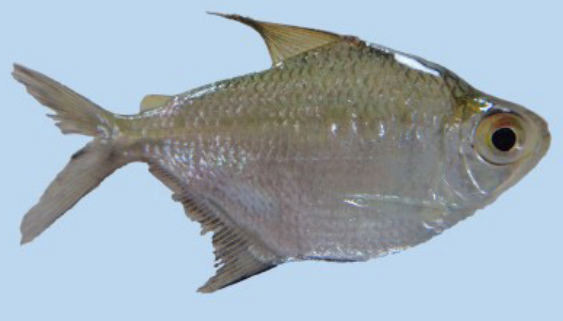

Figure 6: Potamorrhaphis guianensis (a), Leporinus friderici (b), Acestrorhynchus falcirostris (c), Acestrorhynchus falcatus (d), Astyanax sp. (e), Cyanocharax sp. 1 (f), Cyanocharax sp. 2 (g), Hemigrammus rodwayi (h), Hemigrammus sp. (i), Hyphessobrycon bentosi rosaceus (j), Moenkhausia oligolepis (k) and Poptella compressa (j). Scale: 8 mm (e, f, $\mathrm{g}, \mathrm{h}, \mathrm{i}, \mathrm{j}$ e k), $10 \mathrm{~mm}(\mathrm{l}), 30 \mathrm{~mm}$ (b e d) e $50 \mathrm{~mm}$ (a e c) 
a

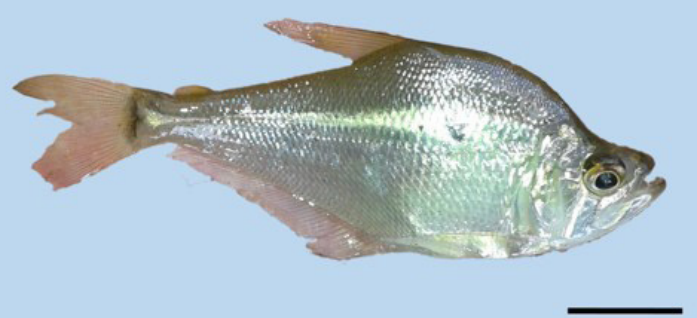

C

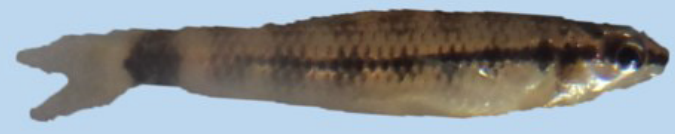

$\mathbf{e}$

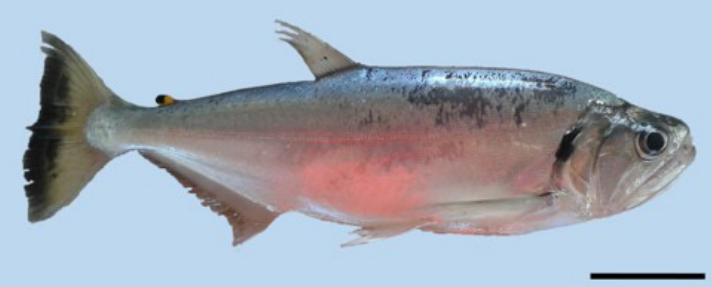

g

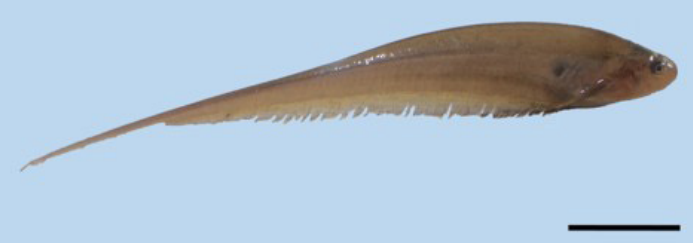

b

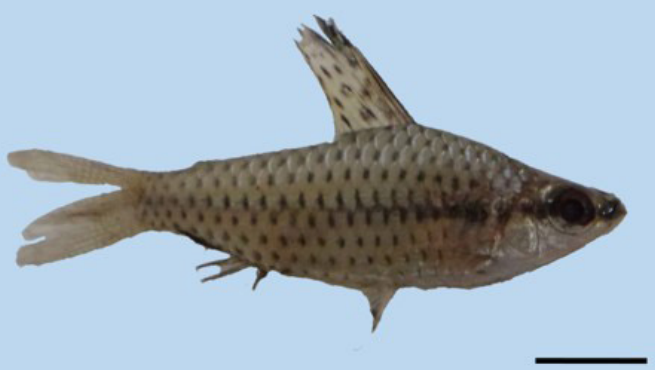

d

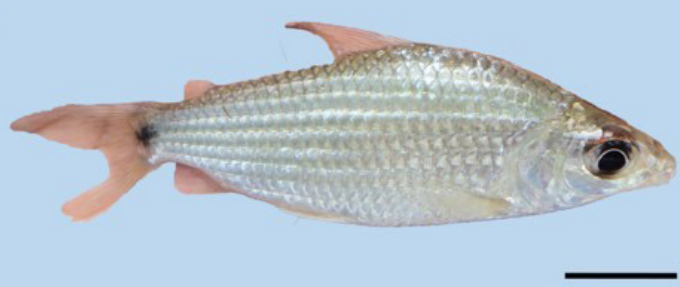

f

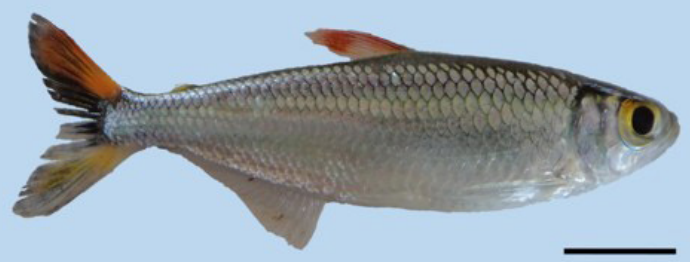

h

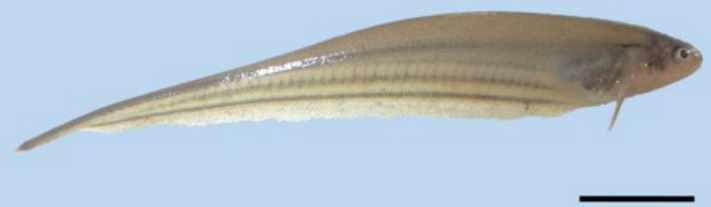

i

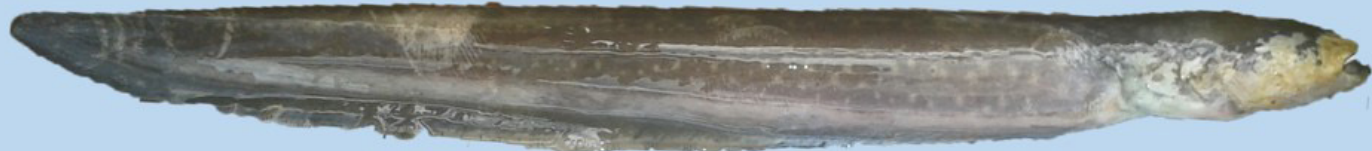

Figure 7: Roeboides affinis (a), Chilodus punctatus (b), Characidium etheostoma (c), Cyphocharax gouldingi (d), Hydrolycus armatus (e), Bryconops giacopinni (f), Rhabdolichops sp. (g), Eigenmannia sp. (h) and Electrophorus electricus (i). Scale: 5 mm (c), 10 mm (b e d), 12 mm (f), 20 mm (a), 40 mm (h), 50 mm (g), 60 mm (i) e 100 mm (e). 
a

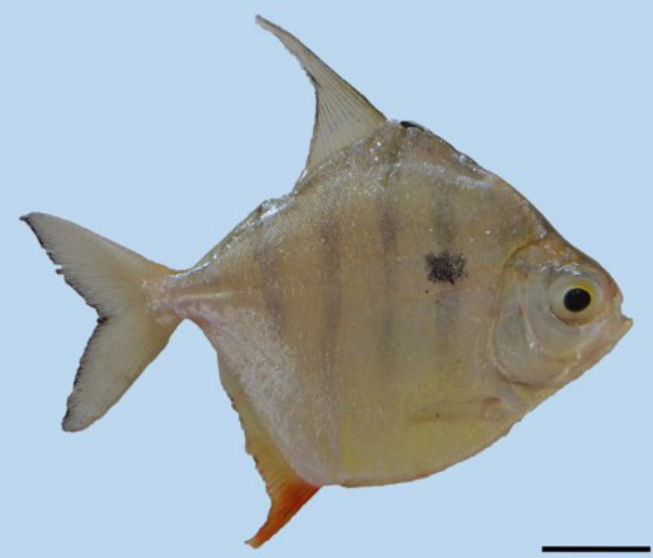

C

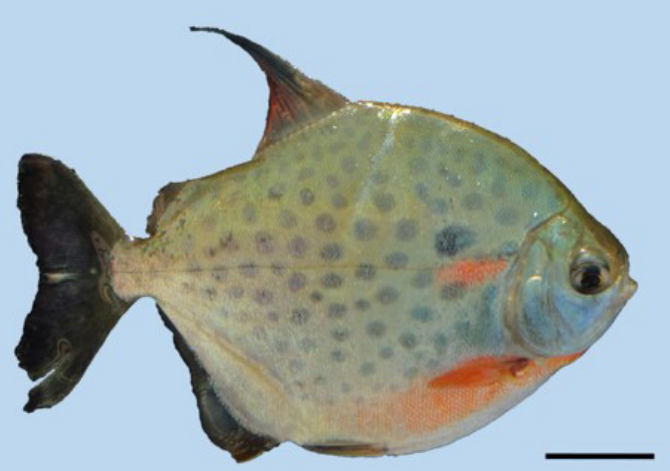

e

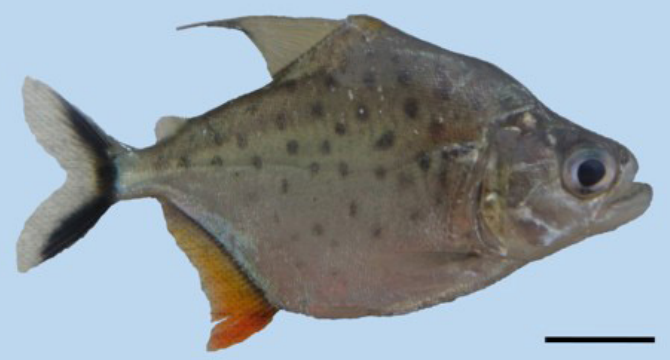

g

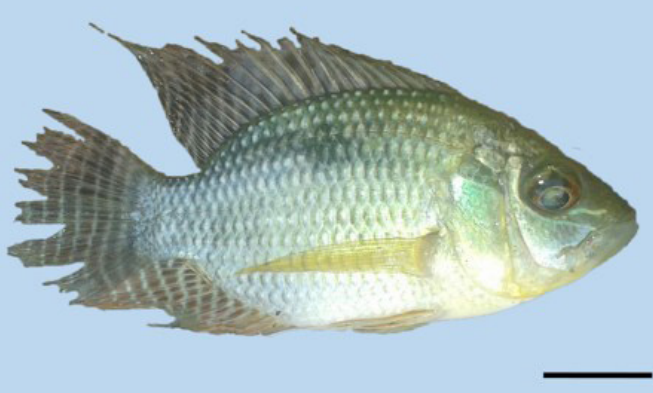

b

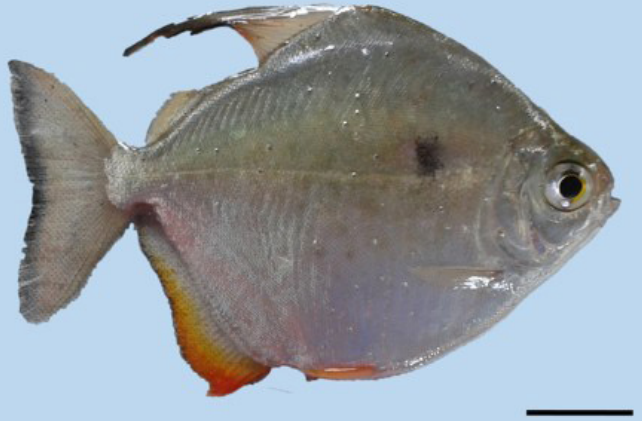

d

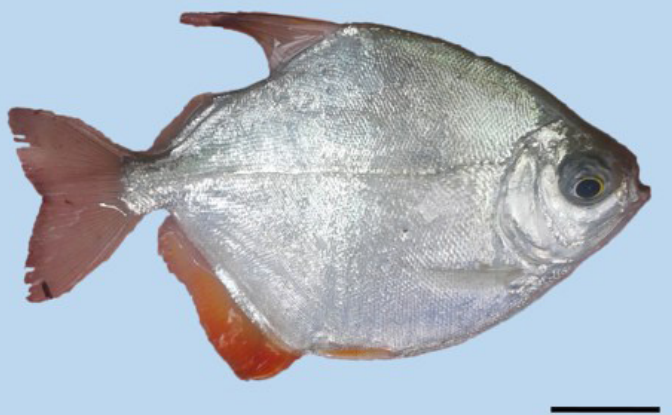

f

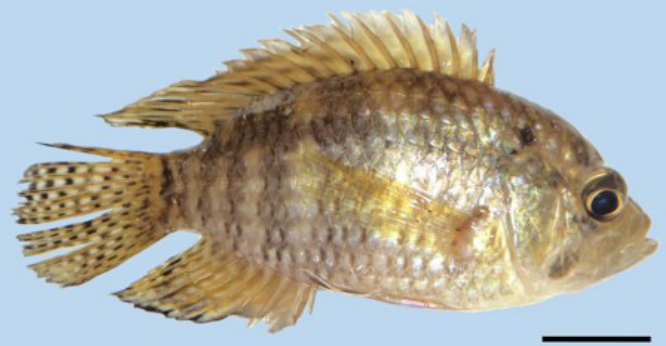

h

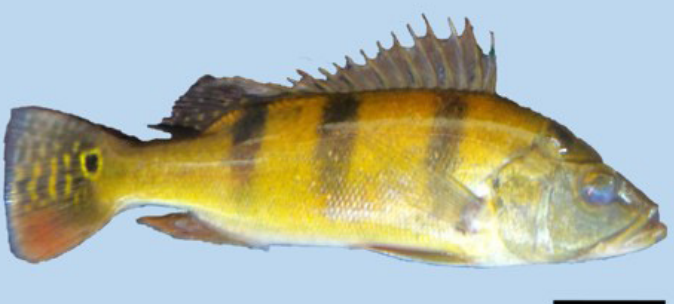

Figure 8: Metynnis fasciatus (a), Metynnis guaporensis (b), Metynnis maculatus (c), Metynnis hypsauchen (d), Serrasalmus altispinis (e), Aequidens sp. (f), Chaetobranchus flavescens (g) and Cichla monoculus (h). Scale: $10 \mathrm{~mm}$ (e), $12 \mathrm{~mm}$ (a), $15 \mathrm{~mm}$ (b), $20 \mathrm{~mm}$ (d e g), $25 \mathrm{~mm}$ (c), 30 mm (f) e $40 \mathrm{~mm}$ (h). 
FOLIA

Amozónica Castanhal, Amazonia oriental

a

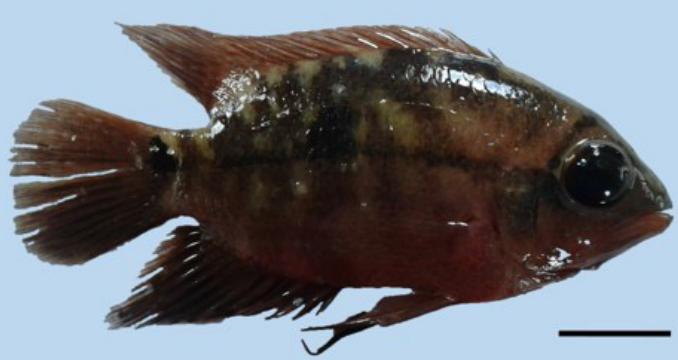

C

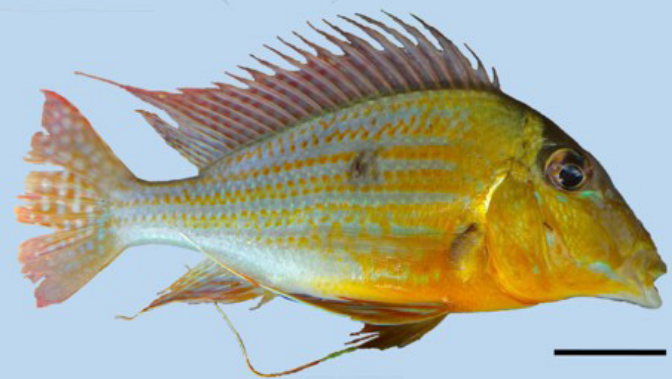

e

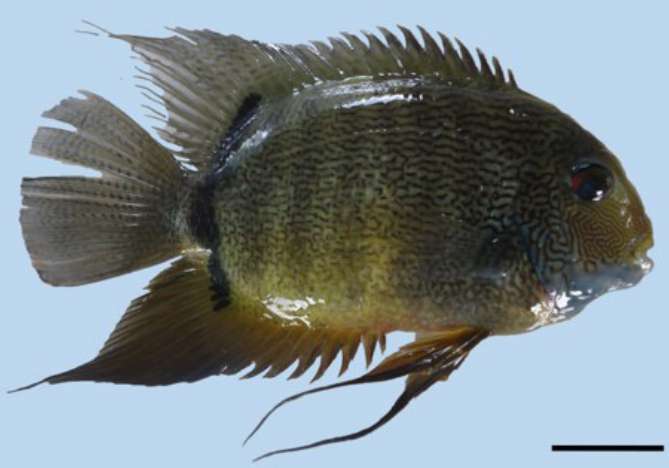

g

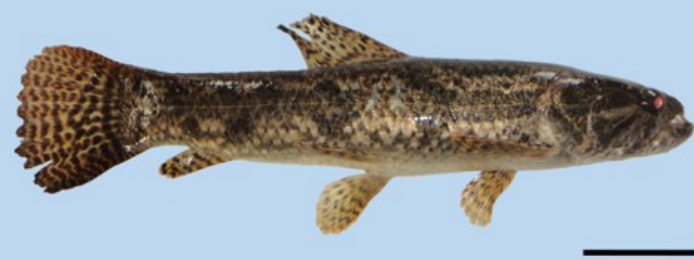

b

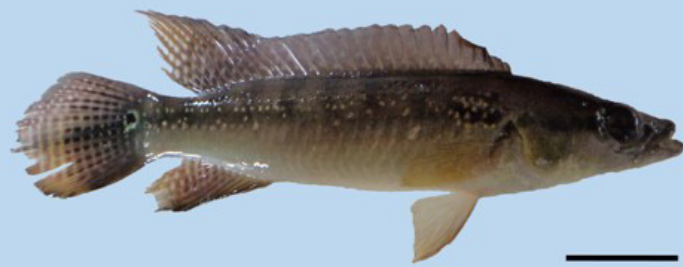

d

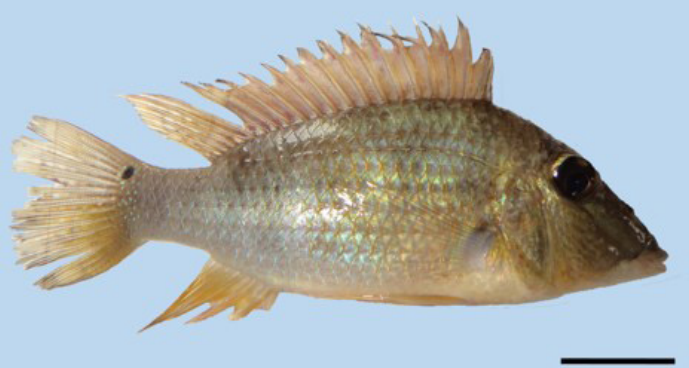

f

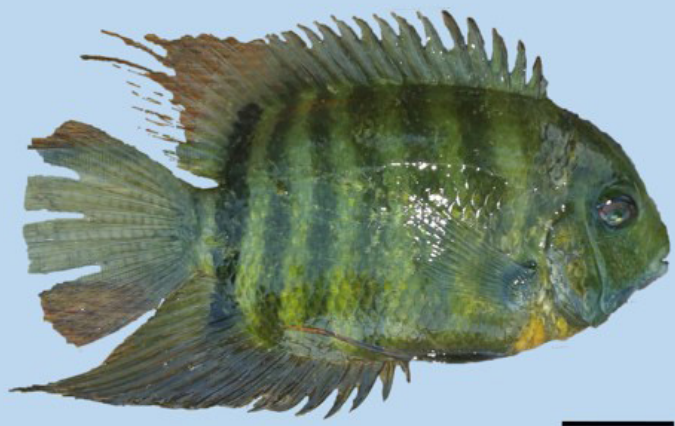

h

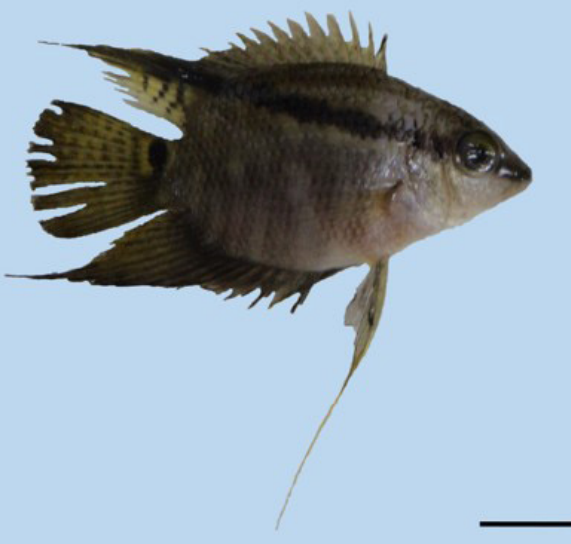

Figure 9: Cichlasoma orientale (a), Crenicichla lepidota (b), Geophagus proximus (c), Satanoperca jurupari (d), Heros efasciatus (e), Heros severus (f), Hoplias malabaricus (g) and Mesonauta festivus (h). Scale: 10 mm (h), 20 mm (a), $30 \mathrm{~mm}$ (c e d), $40 \mathrm{~mm}$ (b, e e f) e $60 \mathrm{~mm}$ (g). 
a

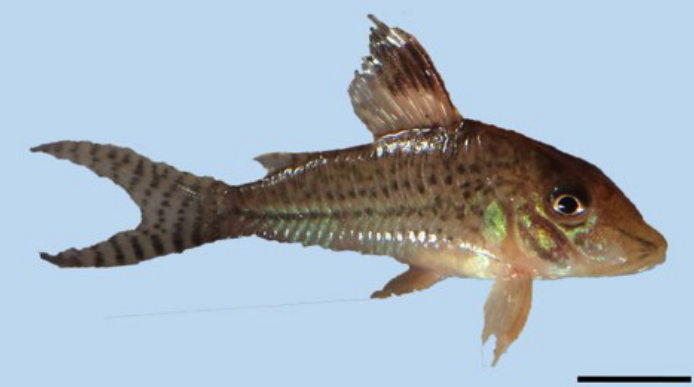

C

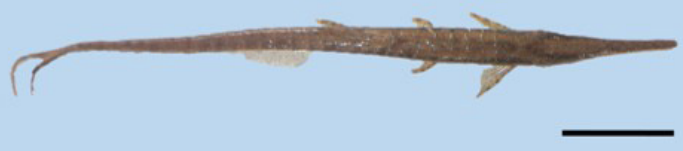

e

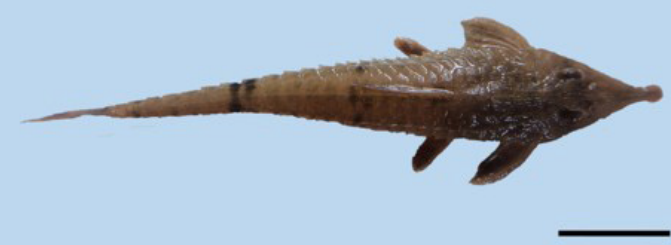

b

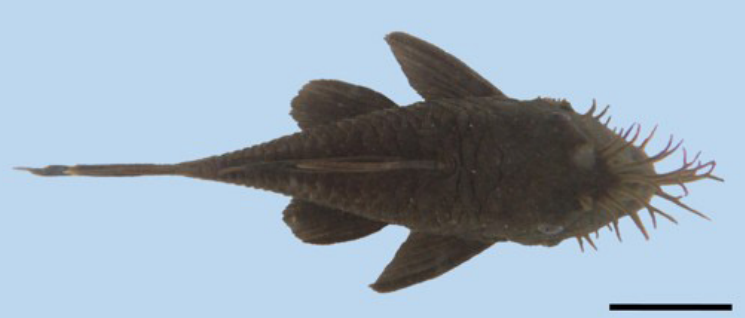

d
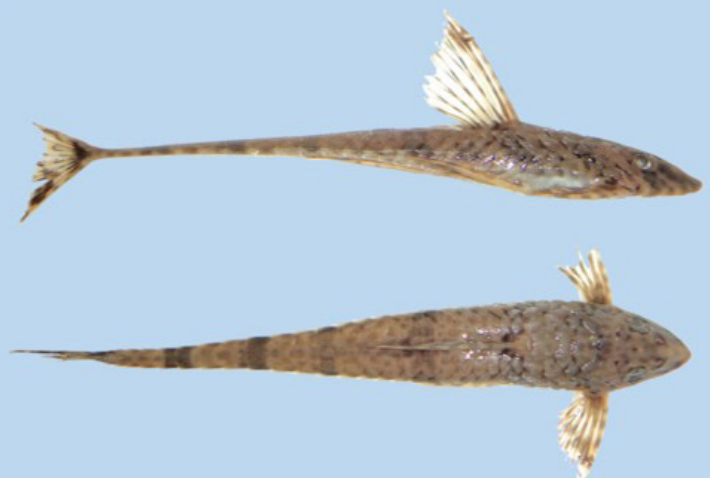

Figure 10: Corydora julii (a), Ancistrus sp. (b), Farlowella hasemani (c), Rineloricaria platyura (d) and Hemiodontichthys acipenserinus (e). Scale: 10 mm (a e b) 20 mm (d e e) e 50 mm (c).

Table I: Fishing nets used in the biological sampling of the Igarapé Praquiquara, indicating the respective mesh size and the places of use (gray color).

\begin{tabular}{|l|llllll|}
\hline Network type & P1 & P2 & P3 & P4 & P5 & P6 \\
\hline Gillnet 1 (mesh 15 mm) & & & & & & \\
Gillnet 2 $(20 \mathrm{~mm})$ & & & & & & \\
Gillnet $3(25 \mathrm{~mm})$ & & & & & & \\
Gillnet $4(30 \mathrm{~mm})$ & & & & & & \\
"Tarrafa" (10 mm) & & & & & \\
Hand trawls $(5 \mathrm{~mm})$ & & & & & \\
Trawls $(5 \mathrm{~mm})$ & & & & \\
\hline
\end{tabular}


Table 2: Abundance of the ichthyofauna found in the Igarapé Praquiquara in the sampled months. Legend: constant species (c), accessory (a) and occasional (o).

\begin{tabular}{|c|c|c|c|c|c|c|c|c|c|c|c|c|}
\hline \multirow{2}{*}{ Order } & \multirow{2}{*}{ Family } & \multirow{2}{*}{ Species } & \multicolumn{4}{|c|}{2014} & \multicolumn{4}{|c|}{2015} & \multirow{2}{*}{ Total } & \multirow{2}{*}{ C } \\
\hline & & & Sep & Oct & Nov & Dec & Jan & Feb & Apr & May & & \\
\hline Beloniformes & Belonidae & Potamorrhaphis guianensis & & & & 2 & & & & & 2 & 0 \\
\hline \multirow[t]{23}{*}{ Characiformes } & Acestrorhynchidae & Acestrorhynchus falcatus & 5 & 3 & & 2 & 1 & 1 & & & 12 & c \\
\hline & & Acestrorhynchus falcirostris & 9 & & 1 & 2 & 2 & 1 & & & 15 & c \\
\hline & Anostomidae & Leporinus friderici & 2 & & & & & & & & 2 & o \\
\hline & Characidae & Astyanax sp. & 40 & & & & 34 & & & & 74 & o \\
\hline & & Cyanocharax sp. & 15 & 1 & & & 9 & 4 & & & 29 & $\mathrm{a}$ \\
\hline & & Cyanocharax sp.2 & & & & & & 3 & & & 3 & $\circ$ \\
\hline & & Hemigrammus rodwayi & & & & & & 14 & & & 14 & $\circ$ \\
\hline & & Hemigrammus sp. & & & & & & 16 & 2 & & 18 & o \\
\hline & & $\begin{array}{l}\text { Hyphessobrycon bentosi } \\
\text { rosaceus }\end{array}$ & 4 & 1 & 2 & 2 & 23 & 1 & & & 33 & c \\
\hline & & Moenkhausia oligolepis & 2 & & 26 & 6 & 4 & & & & 38 & $a$ \\
\hline & & Poptella compressa & & 5 & & & 10 & 4 & & & 19 & a \\
\hline & & Roeboides affinis & & & 7 & & & & & & 7 & o \\
\hline & Chilodontidae & Chilodus punctatus & & 1 & 2 & 1 & & & & & 4 & a \\
\hline & Crenuchidae & Characidium etheostoma & & & & & 1 & & & & 1 & o \\
\hline & Curimatidae & Cyphocharax gouldingi & 10 & 66 & 27 & 6 & 31 & 21 & 4 & 27 & 192 & c \\
\hline & Cynodontidae & Hydrolycus armatus & & 1 & & & & 1 & & & 2 & 0 \\
\hline & Iguanodectidae & Bryconops giacopinni & 22 & & 22 & 20 & 50 & 40 & 49 & 79 & 282 & $\mathrm{a}$ \\
\hline & Serrasalmidae & Metynnis fasciatus & 1 & 2 & & & & & & & 3 & o \\
\hline & & Metynnis guaporensis & & 1 & 3 & 7 & & 2 & & 2 & 15 & c \\
\hline & & Metynnis maculatus & & & & 3 & 1 & 4 & 8 & 8 & 24 & c \\
\hline & & Metynnis hypsauchen & 1 & & & & & 1 & & & 2 & o \\
\hline & & Serrasalmus altispinis & & & 3 & & & & 1 & & 4 & o \\
\hline & Erythrinidae & Hoplias malabaricus & 1 & & & 2 & 1 & 3 & & & 7 & $a$ \\
\hline \multirow[t]{3}{*}{ Gymnotiformes } & Gymnotidae & Electrophorus electricus & & & & 2 & & & & & 2 & o \\
\hline & Sternopygidae & Eigenmannia sp. & & & 2 & & & & & & 2 & o \\
\hline & & Rhabdolichops sp. & & & 2 & & & & & & 2 & o \\
\hline \multirow[t]{10}{*}{ Perciformes } & Cichlidae & Aequidens sp. & & 2 & & 2 & & & & & 4 & o \\
\hline & & Chaetobranchus flavescens & & 6 & & & & & & & 6 & $\circ$ \\
\hline & & Cichla monoculus & 23 & 1 & & 3 & 1 & 2 & 2 & 1 & 33 & c \\
\hline & & Cichlasoma orientale & & 2 & & & & & & & 2 & o \\
\hline & & Crenicichla lepidota & 4 & & & 4 & & & & 1 & 9 & $\mathrm{a}$ \\
\hline & & Geophagus proximus & 4 & 4 & 7 & 5 & & 10 & 17 & 5 & 52 & c \\
\hline & & Heros severus & 4 & 13 & 3 & 15 & 3 & 5 & 2 & 2 & 47 & c \\
\hline & & Heros efasciatus & & & & 2 & 3 & & 4 & 4 & 13 & $a$ \\
\hline & & Mesonauta festivus & & 2 & & & & & 1 & & 3 & o \\
\hline & & Satanoperca jurupari & 8 & 15 & 2 & 11 & 1 & 4 & 3 & 4 & 48 & c \\
\hline \multirow[t]{6}{*}{ Siluriformes } & Callichthyidae & Corydora julii & & & & & 1 & & 2 & & 3 & o \\
\hline & Loricariidae & Ancistrus sp. & & 1 & 4 & & 2 & 4 & 2 & & 13 & c \\
\hline & & Farlowella hasemani & & & 3 & & & & & & 3 & $\circ$ \\
\hline & & $\begin{array}{l}\text { Hemiodontichthys } \\
\text { acipenserinus }\end{array}$ & & & 6 & & 3 & & & & 9 & $\circ$ \\
\hline & & Rineloricaria platyura & & 2 & 5 & & 8 & 5 & & & 20 & $a$ \\
\hline & & Total & 155 & 129 & 127 & 97 & 189 & 146 & 97 & 133 & 1073 & \\
\hline
\end{tabular}


The superiority of Characiformes is reflected in abundance (73.9\%, representing 793 individuals) and species diversity (52.4\%, represented by 22 species), followed by Perciformes (20.9\%, with 224 ind. and 26.2\%, with 11 spp.), Siluriformes (4.5\%, with 48 ind. and $11.9 \%$ with five spp.), Gymnotiformes $(0.6 \%$, with six ind. and 7.1 (with two species) and Beloniformes (0.2\%, with two species and $2.4 \%$ with only one species) (Figure 3).

Cichlidae presented the most diverse family (10 spp.), Followed by Characidae (nine spp.), Serrasalmidae (five spp.), Loricariidae (four spp.), Acestrorhynchidae and Sternopygidae (two spp. with only one species (Figure 4). In relation to the abundance of species, Iguanodectidae was more abundant, with $26.3 \%$ (282 ind.). The other families most abundant were Characidae (20.9\% and 235 ind.), Cichlidae (20.2\% and 217 ind.) and Curimatidae (17.9\% and 192 ind.), the remaining families being less than $10 \%$ of representativeness (Figure 5).

The five most abundant species were Bryconops giacopinni (Fernández-Yépez, 1950) (26.3\%, with 282 ind.) (Figure 7F), Cyphocharax gouldingi Vari, 1992 (17.9\%, with 192 ind.) (Figure 7D ), Astyanax sp. (Heckel, 1840) (4.5\%, with 52 ind.) (Figure 6E), Geophagus proximus (Castelnau, 1855) (4.8\%, with 52 ind.) (Figure 9C) and Satanoperca jurupari (Figure 9D), with only $C$. gouldingi, S. jurupari and Heros severus Heckel, 1840 (Figure 9F) were present in all samples. In relation to the frequency of the species found, 12 were classified as constants, eight by accessory and 22 by occasional (Table 2).

\section{DISCUSSION}

The diversity of species verified in this study (33 spp.) was verified by Anjos et al. (2015) who comments, through a bibliographical review of ichthyofauna surveys in "Igarapés" in the Amazon region, a diversity ranging from 10 to 61 species.

The dominance of Characiformes in the Igarapé Praquiquara was already foreseen, given the abundance of this order, which, together with the Siluriformes, predominate the composition of the Amazonian ichthyofauna (Lowe-McConnell, 1999; Barletta et al., 2010; Brejão et al., 2013; Furtado Jr. et al., 2016; Farias et al., 2017). Súarez (1998) comments that the dominance of Characiformes is attributed to the greater capacity of these fish to obtain oxygen from upper layers of the water column. The higher proportion of Characiformes may represent up to $70 \%$ of the composition (Araújo et al., 2009; Anjos et al., 2015), however, there are studies, as well as Pinheiro et al. (2016) in the Amazon region, which do not present the highest dominance of this order of fish. The low abundance of Siluriformes found in this study was related to their benthic behavior, which made it difficult to capture the specimens with the fishing gear used. Similar results were observed by Costa et al. (2011) in the survey of the ichthyofauna carried out in Lake Catalão, Amazonas and Pinheiro et al. (2016) in Lake Maicá, Santarém.

The greater representativeness of Characidae and Cichlidae in abundance of individuals and species diversity, respectively, is quite common in surveying fish communities in the Amazon, such as, for example, in Marajo Island (Montag et al., 2009), on the river Trombetas (Ferreira, 1993), in the region of Caxiuanã (Montag, 2008) and Lake Maicá (Pinheiro et al., 2016), perpetuating in several other studies. The superiority of these two families was evidenced by Brejão et al. (2013) in several rivers located in the northeast of the state of Pará. The greater abundance of the caracídeos between families evidenced in the Igarapé Praquiquara reflects two characteristics of this group, that usually presents species of small size and with great shoals (Buckup, 1999). 
According Ferreira (1993), species abundance is one of the most important parameters in fish community studies because it reflects the amount of fish in a location. However, it is one of the most difficult parameters to determine in the Neotropical region, since the great diversity of forms and habits presented by the fish (Ferreira, 1993).

Of the species found in the Igarapé Praquiquara, only Corydora julii Steindachner, 1906 (Figure 11A), Hyphessobrycon bentosi rosaceus Durbin, 1909 (Figure 7J), Crenicichla lepidota Heckel (Figure 10B), 1840, Moenkhausia oligolepis (Günther, 1864) (Figure 6K) and Ancistus sp. (Figure 10B) was cited by Carvalho Júnior (2008) as species of ornamental interest distributed in the region. However, there are species found in this study that are economically important for cultivation, fishing or aquaria. (Venere \& Garutti, 2011).

Of the species that make up the ichthyofauna, three are on the IUCN Red List of Threatened Species, classified as a Least Concern, among them the cichlid Crenicichla lepidota Heckel, 1840 (Figure 10B), this classification is attributable to its wide distribution and the absence of threats (Reis \& Lima, 2009a), the gymnotiform Electrophorus electricus (Linnaeus, 1766) (Figure 8I) due to its large distribution, their ability to occupy a variety of habitats and the absence of any widespread threats of major importance to this species (Reis \& Lima, 2009c) and the caracid Roeboides affinis (Günther, 1868) (Figure 7A), present in this classification due to being a species is extremely widespread, common and not threatened (Reis \& Lima, 2009b).

The presence of harmful fish, such as $E$. electricus, in areas where there is a constant presence of the public (e.g., academic activities), must be registered, as well as done by Chagas et al. (2017).

Vol. 28 (1) 2019. 1-17
Record of occurrence of species are of vital importance, not only in the Amazon region, but in all national territory (Aloísio et al., 2005; Chagas \& Barros, 2018), due mainly to the presence of several large hydrographic systems in Brazil, which reflects a high diversity of freshwater fish, presenting a considerable distinction in the diversity of each other (Chagas et al., 2017).

The conservation of Amazonian ichthyofunistic diversity is important, mainly due to the anthropic impacts, which causes many species to extinct even before being cataloged (Barletta et al., 2010).

The ichthyofauna of the Igarapé Praquiquara is composed of fish belonging to five large taxa, predominantly Characiformes and Perciformes, mainly due to the abundances of the Characidae and Cichlidae families. Also noteworthy are the presence of species of commercial food interest (e.g. Leporinus friderici) and the branch of aquarium (e.g. Heros severus and Corydora julii).

It is necessary to monitor the quality of water in the Igarapé Praquiquara due to the presence of the fishery of the UFRA and several pasture areas and agricultural farms around the stream, which may result in the disposal of effluents in the water body.

It is recommended an analysis of the structure of the fish community, in order to verify which factors are determinant for the composition of the ichthyofauna of Igarapé Praquiquara, analyzing the influence, for example, between seasonal periods, trophic levels and above all the influence of the dam species dispersal, distribution and reproduction.

\section{ACKNOWLEDGMENTS}

To the Instituto Socioambiental e dos Recursos Hídricos (ISARH) and the Universidade Federal Rural da Amazônia (UFRA) for the logistic support to the execution of this work. To the manager of the 
Fazenda Escola de Castanhal (FEC), Agronomist Raimundo Nonato Silva (Raimundinho) and the Téc. Agropecuário Joaquim dos Santos (Maradona), for the receptivity to the students who participate in activities at the FEC.

\section{REFERENCES}

Aloísio, G.R., Oliveira, F.G., Angelini, R. 2005. Fish, State Park of Jalapão, State of Tocantins, Brazil. Check List, 1(1): 10-13. http://dx.doi. org/10.15560/1.1.10

Anjos, M.R., Manzatto, Â.G., Machado, N.G. 2015. Assembleias de peixes em Igarapés de terra firme em duas sub-bacias do médio rio Madeira, Brasil. Evolução e Conservação da Biodiversidade, 6(1): 1-11. DOI: 10.7902/ecb. v6i1.72

Araújo, T.R., Ribeiro, A.C., Doria, C.R.C., TorrenteVilara, G. 2009. Composition and trophic structure of the ichthyofauna from a stream downriver from Santo Antonio Falls in the Madeira River, Porto Velho, RO. Biota Neotropica, 9(3): 21-29. http://dx.doi. org/10.1590/S1676-06032009000300001

Barletta, M., Jaureguizar, A.J., Baigún, C., Fontoura, N.F., Agostinho, A.A., Almeida-Val, V.M.F., Val, A.L., Torres, R.A., Jimenes-Segura, L.F., Giarrizzo, T., Fabré, N.N., Batista, V.S., Lasso, C.A., Taphorn, D.C., Costa, M.F., Chaves, P.T., Vieira, J.P., Corrêa, M.F.M. 2010. Fish and aquatic habitat conservation in South America: a continental overview with emphasis on neotropical systems. Journal of Fish Biology, 76(2118-76. doi:10.1111/j.1095-8649.2010.02684.x

Bastos, D.A. 2013. Variação interanual da composição das assembléias de peixes em quatro micro-bacias do nordeste paraense. Dissertação (mestrado em Ciências Biológicas), Instituto Nacional de Pesquisas da Amazônia, Manaus, 106pp.
Brejão, G.L., Gerhard, P., Zuanon, J. 2013. Functional trophic composition of the ichthyofauna of forest streams in eastern Brazilian Amazon. Neotropical Ichthyology, 11(2): 361-73. http://dx.doi.org/10.1590/ S1679-62252013005000006

Buckup, P.A. 1999. Sistemática e biogeografia de peixes de riachos. In: Caramaschi, E.P., Mazzoni, R., \& Peres-Neto, P.R. (Eds) Ecologia de Peixes de Riachos. PPGE-UFRJ, Rio de Janeiro, p. 91-138. Buckup, P.A., Menezes, N.A., Ghazzi, M.S.A. 2007. Catálogo das espécies de peixes de água doce do Brasil. Museu Nacional, Rio de Janeiro, 195pp.

Carvalho Júnior, J.R. 2008. A composição da ictiofauna de interesse ornamental no estado do Pará. Dissertação (Mestrado em Ecologia Aquática e Aquicultura), Universidade Federal do Pará, Belém - PA, 98pp.

Cáuper, G.C.B. 2006. Biodiversidade amazônica Flora amazônica Centro Cultural dos Povos da Amazônia - CCPA, Manaus, 164pp.

Cervigón, F., Cipriani, R., Fischer, W., Garibaldi, L., Hendrickx, M., Lemus, A.J., Márquez, R., Poutiers, J.M., Robaina, G., Rodriguez, B. 1992. Guia de campo de las especies comerciales marinas y de agua salobres de la costa septentrional de sur america. FAO, Roma, 577pp.

Chagas, R.A., Barros, M.R.F. 2018. Increased geographical distribution of Potamorrhaphis guianensis (Jardine, 1843) in the Brazilian Amazon region. Brazilian Journal of Biological Sciences, 5(11): 627-30. https://doi. org/10.21472/bjbs.051101

Chagas, R.A., Barros, M.R.F., Santos, R.F., Duarte, L.B., Pereira, C.M.B., Noronha, G.S.T., Brito, L.C.R. 2017. Abundance and photographs of the ichthyofauna of the Praquiquara Igarapé, Pará State, Brazil. PANGAEA - Data Publisher for Earth \& Environmental Science. Disponible: https:// doi.pangaea.de/10.1594/PANGAEA.871600

Chagas, R.A., Barros, M.R.F., Santos, W.C.R., Herrmann, M. 2017. Primeiro registro do peixe- 
elétrico Electrophorus electricus (Linnaeus, 1766) (Gymnotiformes: Gymnotidae) no Igarapé Praquiquara, Castanhal, Pará. Acta of Fisheries and Aquatic Resources, 5(1): vi-xi. DOI 10.2312/ActaFish. 2017.5.1.vi-xi

Costa, I.D., Rocha, A.C.P.V., Lima, M.A.C., Zuanon, J.A.S. 2011. Composição e abundância de peixes da interface entre as águas abertas e bancos de macrófitas e sua dinâmica nos períodos de crepúsculos matutino e vespertino, no lago Catalão, Amazonas, Brasil. Biotemas, 24(2): $97-$ 101. doi: 10.5007/2175-7925.2011v24n2p97

Farias, E.U., Loebens, S.C., Yamamoto, K.C., Siqueira-Souza, F.K., Freitas, C.E.C., Anjos, H.D.B., Magalhães, E.R.S. 2017. Assembleia de peixes em lagos do rio Quiuini, um tributário do rio Negro, Amazonas, Brasil. Biota Amazônia, 7(1): 74-81. http://dx.doi.org/10.18561/21795746/biotaamazonia.v7n1p74-81

Ferreira, E.J.G. 1993. Composição, distribuição e aspecto ecológicos da ictiofauna de um trecho do rio Trombetas, naárea de influência da futura UHE Cachoeira Porteira, Estado do Pará, Brasil. Acta Amazonica, 23(suplemento): 1-89. http:// dx.doi.org/10.1590/1809-43921993235089

Furtado Jr., I., Souza, R.A.L., Santos, E.T., Souza, A.C.P., Carvalho Jr., J.R., Oliveira, A.H.M. 2016. Avaliação dos estoques da ictiofauna na barragem da mina de Sossego em Canaã dos Carajás (Amazônia Oriental), capturados com uso de tarrafa, antes do depósito de rejeitos. Biota Amazônia, 6(4): 26-31. http://dx.doi. org/10.18561/2179-5746/biotaamazonia. v6n4p26-31

Géry, J. 1977. Characoids of the world. Publications, Inc. Ltd., Neptune,

Krebs, C.J. 1978. Ecology: The experimental analysis of distribution and abundance. Harper \& Row, New York, 678pp.

Lowe-McConnell, R.H. 1999. Ecological studies in tropical fish communities. Edusp, São Paulo, $321 \mathrm{pp}$.
Montag, L.F.A., Albuquerque, A.A., Freitas, T.M.S., Barthem, R.B. 2009. Ictiofauna de campos alagados da Ilha de Marajó, Estado do Pará, Brasil. Biota Neotropica, 9(3): 24153. $\quad$ http://dx.doi.org/10.1590/S167606032009000300024

Montag, L.F.A., Freitas, T.M.S., Wosiacki, W.B., Barthem, R.B. 2008. Os peixes da Floresta Nacional de Caxiuanã (municípios de Melgaço e Portel, Pará - Brasil). Boletim do Museu Paraense Emílio Goeldi. Ciências Naturais, 3(1): 11-34. Disponible: http://scielo.iec.gov.br/ pdf/bmpegcn/v3n1/v3n1a02.pdf

Moraes, B.C., Costa, J.M.N., Costa, A.C.L., Costa, M.H. 2005. Variação espacial e temporal da precipitação no estado do Pará.Acta Amazonica, 35(2): 207-14. http://dx.doi.org/10.1590/ S0044-59672005000200010

Nelson, J.S. 2006. Fishes of the World. John Wiley \& Sons, Inc, Canada,

Nogueira, C., Buckup, P.A., Menezes, N.A., Oyakawa, O.T., Kasecker, T.P., Ramos Neto, M.B., da Silva, J.M. 2010. Restricted-range fishes and the conservation of Brazilian freshwaters. PLoS ONE, 5(6): e11390. 10.1371/journal. pone.0011390

Pará. 2012. Política de Recursos Hídricos do Estado do Pará. SEMA, Belém,

Pinheiro, D.T., Corrêa, J.M.S., Chaves, C.S., Campos, D.P.F., Pontes, S.C.S.d., Zacarde, D.M. 2016. Diversidade e distribuição da ictiofauna associada a bancos de macrófitas aquáticas de um lago de inundação amazônico, estado do Pará, Brasil. Acta of Fisheries and Aquatic Resources, 4(2): 59-70. DOI 10.2312/ ActaFish.2016.4.2.59-70

Queiroz, L.J., Torrente-Vilara, G., Ohara, W.M., Pires, T.H.S., Zuanon, J., Doria, C.R.C. 2013a. Peixes do rio Madeira. São Paulo: Santo Antônio Energia, 416pp.

Queiroz, L.J., Torrente-Vilara, G., Ohara, W.M., Pires, T.H.S., Zuanon, J., Doria, C.R.C. 2013b. 
Peixes do rio Madeira. São Paulo: Santo Antônio Energia, 354pp.

Queiroz, L.J., Torrente-Vilara, G., Ohara, W.M., Pires, T.H.S., Zuanon, J., Doria, C.R.C. 2013c. Peixes do rio Madeira. Santo Antônio Energia, São Paulo, 402pp.

Reis, R., Lima, F. 2009a. Crenicichla lepidota. The IUCN Red List of Threatened Species. http:// dx.doi.org/10.2305/IUCN.UK.2009-2.RLTS. T167717A6372093.en.

Reis, R., Lima, F. 2009b. Roeboides affinis. The IUCN Red List of Threatened Species. http:// dx.doi.org/10.2305/IUCN.UK.2009-2.RLTS. T167642A6361596.en.

Reis, R.E., Lima, F. 2009c. Electrophorus electricus. The IUCN Red List of Threatened Species. http:// dx.doi.org/10.2305/IUCN.UK.2009-2.RLTS. T167700A6369863.en.

Rodrigues, W.C. 2010. Estatística Aplicada. W.C. Rodrigues, Paracambi, 70pp.

Santos, G.M., Ferreira, E.J.G., Zuanon, J.A.S. 2006. Peixes comerciais de Manaus. Ibama/AM. ProVárzea, Manaus, 144pp.

Santos, G.M., Jegu, M., Merona, B. 1984. Catalago de peixes comerciais do baixo rio Tocantins. Eletronorte/CNPq/Inpa, Manaus, 86pp.

Santos, G.M., Mérona, B., Juras, A.A., Jégu, M. 2004. Peixes do Baixo Rio Tocantins: 20 anos depois da Usina Hidrelétrica Tucuruí. Eletronorte, Brasília, 216pp.

Santos, R.F., Chagas, R.A. 2016. Análise morfométrica de Cyphocharax gouldingi (Vari, 1992) (Characiformes: Curimatidae) da microbacia do rio Praquiquara, médio Apeú, Amazônia Oriental. Acta of Fisheries and Aquatic Resources, 4(1): 54-61. DOI 10.2312/ ActaFish.2016.4.1.54-61

Silva, R.S., Palheta, G.D.A., Nascimento, Á.M., Rocha, C.P., Reis, S.H.O., Melo, N.F.A.C. 2011. Qualidade da água e composição zooplanctônica em viveiros de piscicultura (Castanhal, Pará). Boletim Técnico Científico do Cepnor, 11(1): 45-58. Disponible: https://cepnor.ufra.edu.br/ index. hp?journal=tjfas\&page $=$ article $\& o p=$ vie w\&path\%5B\%5D=1202\&path\%5B\%5D=330

Soares, M.G.M., Costa, E.L., Siqueira-Souza, F.K., Anjos, H.D.B., Yamamoto, K.C., Freitas, C.E.C. 2008. Peixes de lagos do Médio Rio Solmões. Instituto I-Piatam, Manaus, 176pp.

Súarez, Y.R. 1998. Fish community ecology in lakes of the Pantanal Nhecolândia, Corumbá, Mato Grosso do Sul. Dissertação (Mestrado em Ecologia), Universidade Federal do Mato Grosso, Cuiabá, 53pp.

Venere, P.C., Garutti, V. 2011. Peixes do Cerrado Parque Estadual da Serra Azul - Rio Araguaia, MT. Rima Editora, Fapemat, São Carlos, 220pp. Vieira, F.G., Matsuzaki, A.A., Barros, B.S.F., Ohara, W.M., Paixão, A.C., Torrente-Vilara, G., Zuanon, J., Doria, C.R.C. 2016. Catálgo de pexies da ESEC Cuniã. Edufro, Porto Velho, 108pp.

Zuanon, J., Mendonça, F.P., Espírito-Santo, H.M.V., Dias, M.S., Galuch, A.V., Akama, A. 2008. Guia de Peixes da Reserva Adolpho Ducke - Amazônia Central. Manaus: [s.n.], 170pp.

Recibido: 26 de enero de 2019 Aceptado para publicación: 24 de mayo de 2019

Esta obra está bajo una Licencia Creative Commons Atribución-NoComercial-SinDerivar 4.0 Internacional. 